\title{
Experimental and Modeling Study of Soil Water Retention Curves of Compacted Bentonite considering Salt Solution Effects
}

\author{
Yong $\mathrm{He} \mathbb{B}^{1,2,3}$ Ke-neng Zhang, ${ }^{1,2}$ and Dong-yu $\mathrm{Wu}^{1,2}$ \\ ${ }^{1}$ Key Laboratory of Metallogenic Prediction of Nonferrous Metals and Geological Environment Monitoring (Central \\ South University), Ministry of Education, China \\ ${ }^{2}$ School of Geosciences and Info-Physics, Central South University, Changsha 410083, China \\ ${ }^{3}$ Key Laboratory of Geotechnical \& Underground Engineering of Ministry of Education and Department of Geotechnical Engineering, \\ Tongji University, Shanghai 200092, China
}

Correspondence should be addressed to Yong He; heyong18@csu.edu.cn

Received 20 December 2018; Accepted 25 February 2019; Published 5 May 2019

Academic Editor: Huazhou Li

Copyright (C) 2019 Yong He et al. This is an open access article distributed under the Creative Commons Attribution License, which permits unrestricted use, distribution, and reproduction in any medium, provided the original work is properly cited.

\begin{abstract}
Due to its low hydraulic conductivity, high swelling capacity, and good adsorption properties, the Gaomiaozi (GMZ) bentonite has been selected as potential buffer/backfill materials for construction of engineered barriers in the deep geological repository for disposal of high-level nuclear waste (HLW) in China. Investigation of salt solution effects on the water retention properties of compacted bentonite is of great importance in the context of geological disposal of HLW based on the multibarrier concept. In this study, amended specimens were obtained through a spray of different concentrations of salt solutions to reach target salt contents, respectively. With employment of the vapor phase technique for suction control, water retention tests were conducted on densely compacted GMZ bentonite $\left(1.7 \mathrm{Mg} / \mathrm{m}^{3}\right)$ with different salt contents under confined conditions. Corresponding soil water retention curves (SWRCs) were obtained. Analysis indicates that, for a given suction, the measured water content of GMZ bentonite specimen increases as the salt content (or pore fluid concentration) increases. The influencing rate depends on suction. For lower suctions (lower than $38 \mathrm{MPa}$ ), the water retention capacity increases as the salt content increases, while for higher suctions (higher than $38 \mathrm{MPa}$ ), the influence can be negligible. Based on the Fredlund and Xing (1994) equation, a soil water retention model was proposed for simulation of the SWRCs of compacted GMZ bentonite with consideration of pore fluid chemistry. Parameters were analyzed and determined with consideration of influences of the pore fluid concentration. Verification indicates that the SWRCs simulated by the proposed model are well agreed with the measured ones.
\end{abstract}

\section{Introduction}

Compacted bentonite has been recommended as a buffer/backfill material in many countries for engineered barriers in the deep geological repository for disposing high-level nuclear waste (HLW) [1-9]. The compacted bentonite will undergo a complex-highly coupled thermal $(\mathrm{T})$, hydro $(\mathrm{H})$, mechanical $(\mathrm{M})$, and chemical $(\mathrm{C})$ - process during the long-term operation of a repository [10-12], i.e., simultaneous heating from decay of nuclear waste in the canister, infiltration of groundwater from the surrounding geological formations, possible leakage of nuclides from the canister, and swelling pressure of bentonite on hydration. To assess these coupled processes of the engineered barrier system, a number of investigations have been conducted $[1,3,9,13-15]$ and related modeling approaches [16-18] have been proposed.

The resaturation of the initially unsaturated repositories is predicted to last hundreds of years after the closure of a repository $[19,20]$. During this period, it is inevitable for the saturation/water content of the compacted bentonite to increase by groundwater ingress or decrease by evaporation because of high temperature $\left(50-210^{\circ} \mathrm{C},[21]\right)$ originating from decay heat. Thus, the compacted bentonite will experience cyclic wetting/drying processes accompanied by cyclic salinization-desalination, which could be enhanced by the coupling effects of the sanity groundwater intrusion and the possible water evaporation, or the ingress of fresh 
groundwater. Therefore, the salt content or fluid concentration in the compacted bentonite will also undergo cyclic processes, which results in alterations of properties of the compacted bentonite [22].

The soil water retention curve (SWRC) has been widely used to evaluate unsaturated soil properties, including saturated and unsaturated permeability functions, shear strength parameters, and volume change [15, 23]. Meanwhile, in unsaturated soils, modeling of water distribution and flow needs knowledge of SWRC, which also plays a key role in water management and predicting transportation of solute and contaminant in the environment [24]. As an important hydraulic characteristic, water retention is closely correlated with the size and connectivity of soil pore space; therefore, it is strongly influenced by the texture and structure of the soil and other components such as soil organic matter [25]. Hence, it is important to have a reasonably accurate and more practical characterization of the SWRC.

It is generally agreed that direct measurement of SWRC in the laboratory requires hard work and is timeconsuming [26]. Therefore, many empirical equations were developed for description of the SWRC in the past decades [24, 27-30]. For compacted bentonite, modified water retention models were also developed with consideration of temperature and dry density effects [31, 32]. These equations are composed of two or three fitting parameters, which are evaluated by using either laboratory results at different moisture contents or statistical relationships between the suction and other basic soil properties.

Lots of factors can influence the SWRC of geomaterials, including soil type, initial water content, mineralogy, density, temperature, texture, stress history, method of compaction, and net confining stress. In this regard, various investigations [33-36] have been conducted. Meanwhile, experimental results also indicated that the salt concentration of infiltrating groundwater can influence the water retention properties of compacted bentonite/expansive clay specimens when used as buffer/backfill materials in the HLW repository [37-39]. For wetting or drying with a given concentration pore fluid, Fredlund and Xing [28] assumed that the maximum osmotic suction in less active soils is approximately $1.5 \mathrm{MPa}$. It is worth noting that osmotic suction changes may be of importance in some cases. For instance, the effect of osmotic suction is significant when the soil salt content is in a high level [40]. Thyagaraj and Rao [35] also found that the osmotic suction, derived by salt water, should not be ignored in the suction measurement of an Indian bentonite. This observation could be confirmed by Mata et al. [38] with measurement of the water retention curve of MX- 80 bentonite/sand mixture, in which different concentrations of salt solutions were used to speed up the saturation process. In Europe, the Boom Clay, which is a $100 \mathrm{~m}$ thick marine clay, presents favorable properties to limit and delay the migration of the leached radionuclides over extended periods of time. Based on the measurement of suction of Boom Clay containing $\mathrm{NaNO}_{3}$ solution using the chilled-mirror psychrometer (WP4 Dewpoint Potential Meter) and investigation of the corresponding changes of the microstructure of the specimen tested with the MIP (mercury intrusion porosimetry) technique, Mokni [41] stated that the total suction of specimens saturated with salt solution was higher compared with that of specimens saturated with distilled water, while the matric suction in the salt solution-saturated group was smaller than that in the distilled water-saturated group.

China's deep geological disposal program for HLW began in the 1980s. Beishan of Gansu has been selected as the preferred site for construction of repository in China $[23,37]$. Bentonite from Gaomiaozi (GMZ), $300 \mathrm{~km}$ northwest of Beijing, has been reckoned as the preferred "buffer/backfill material” for building engineering barriers in deep geological repositories [37].

Efforts have been made to thoroughly understand the water retention property of GMZ bentonite in recent years [30, 42-46]. Chen et al. [42] measured the SWRCs of the densely compacted GMZ bentonite at room temperature $\left(20^{\circ} \mathrm{C}\right)$ under confined and free swelling conditions using the vapor phase technique and the osmotic technique. Results show that influence of confining conditions on water retention depends on suction, and it becomes less significant as the suction increases from $4.2 \mathrm{MPa}$. For considering temperature effects, Ye et al. [46] measured SWRCs of GMZ bentonite at different temperatures and reported that temperature effects on the soil-water characteristics depend strongly on the constraint conditions. For unconfined compacted GMZ bentonite specimens, the effect of temperature on the hysteresis behaviour is related to the suction level: a negative correlation between hysteresis behaviour and temperature. Based on these and a comprehensive review of literatures [27, 28, 31, 47], Wan [30] extended the Fredlund and Xing [28] equation for description of water retention curves at room temperature $\left(20^{\circ} \mathrm{C}\right)$ to a novel one that can consider temperature effects.

According to in situ investigations in Beishan, the average dissolved solid (TDS) concentration of groundwater is in the range of $3 \mathrm{~g} / \mathrm{L}$ to $12 \mathrm{~g} / \mathrm{L}$, with a maximum up to $50 \mathrm{~g} / \mathrm{L}[48,49]$. Apparently, the influence of salt solution on water retention of GMZ bentonite becomes a key issue to be reckoned with and of significance to China's HLW disposal project.

In this work, GMZ bentonite powder with different salt contents was obtained after being sprayed with different concentrations of $\mathrm{NaCl}$ solutions. The specimens were prepared by compacting the amended bentonite powder to target dimensions and dry density. Suction-controlled water retention tests were carried on with the compacted amended GMZ bentonite specimens under confined conditions. Based on these, a modified soil water retention model for the compacted GMZ bentonite with consideration of salt solution concentration effects was established and verified.

\section{Materials and Methodology}

2.1. Materials and Specimen Preparation. The material tested in this work is GMZ bentonite. The GMZ bentonite was sampled in the northern Chinese Inner Mongolia autonomous region, $300 \mathrm{~km}$ northwest from Beijing. There are 160 million tons with 120 million tons of $\mathrm{Na}$-bentonite reserves in the deposit (Figure 1), and the mine area is about $72 \mathrm{~km}^{2}$. The 


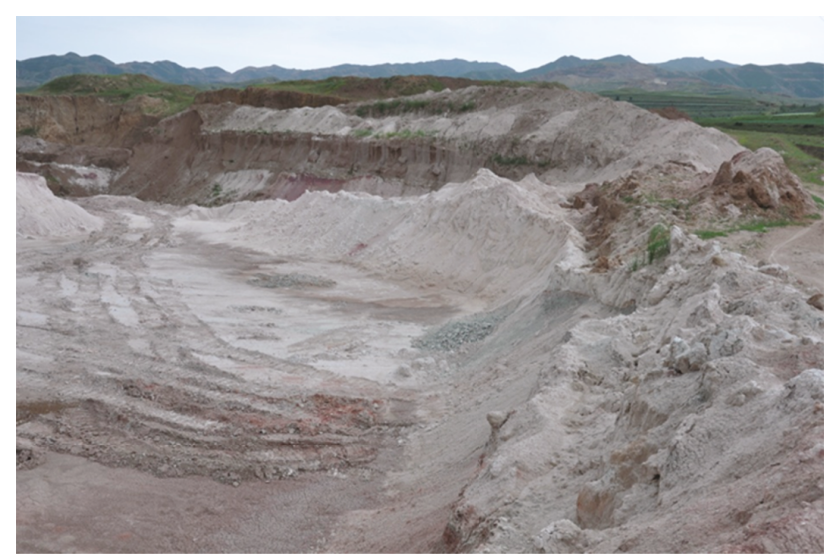

Figure 1: Open pit of GMZ bentonite deposit.

GMZ bentonite used in this work belongs to a Na-type bentonite. The bulk chemical components of the sample were analyzed using $\mathrm{X}$-ray fluorescence spectrometry as follows (in mass): $\mathrm{SiO}_{2}$ 67.43\%, $\mathrm{Al}_{2} \mathrm{O}_{3} 14.20 \%, \mathrm{Fe}_{2} \mathrm{O}_{3} 2.40 \%, \mathrm{Na}_{2} \mathrm{O}$ $1.75 \%, \mathrm{CaO} 1.13 \%, \mathrm{~K}_{2} \mathrm{O} 0.73 \%, \mathrm{FeO} 0.29 \%, \mathrm{TiO}_{2} 0.12 \%$, $\mathrm{MgO} 0.10 \%, \mathrm{P}_{2} \mathrm{O}_{5} 0.02 \%$, and $\mathrm{MnO} 0.02 \%$. In addition, GMZ bentonite contains some lanthanides, such as La, Ce, and $\mathrm{Nd}[50,51]$. Relevant properties of this bentonite are listed in Table $1[14,50,51]$. A high cation exchange capacity and adsorption ability can be identified. The XRD test results (Figure 2) show that the characteristic diffraction peaks of the plane at $6.03^{\circ}, 20.0^{\circ}$, and $35.0^{\circ}$ in $2 \theta$ values and the corresponding basal spacing are $14.70,4.44$, and $2.50 \AA$, respectively, indicating that the main compound in the specimens tested in the present work is montmorillonite (M). The XRD pattern also indicates the existence of quartz (Q: $26.8^{\circ}$ ), cristobalite (Cri: $22.2^{\circ}$ ), and albite (Al: $28.1^{\circ}$ ) [52].

For most investigations involving chemical effects on the hydromechanical behaviours of soils in the laboratory, various methods were developed for specimen preparation: (1) mixing the soil powder with desired solution, (2) immersing a soil specimen in a solution, and (3) percolating a soil specimen by solution [53]. Mixing the GMZ bentonite powder with desired solutions was employed for the specimen preparation in this work.

Following this aspect, a pretreating course was conducted. The GMZ bentonite powder with an initial water content of $11.7 \%$ was dried in an oven at $105^{\circ} \mathrm{C}$ for $24 \mathrm{~h}$. After that, distilled water and $0.5 \mathrm{~mol} / \mathrm{L}, 1.0 \mathrm{~mol} / \mathrm{L}$, and $1.5 \mathrm{~mol} / \mathrm{L}$ $\mathrm{NaCl}$ solutions were sprayed on the bentonite powder to achieve a target water content of $20 \%$, respectively. The mass ratio of salt and bentonite was defined as $R_{\mathrm{s}}(\mathrm{mol} / \mathrm{g})$, and corresponding salt contents of the amended bentonite powder are listed in Table 2. After being self-cured in sealed boxes for about $60 \mathrm{~h}$, the amended bentonite powder was dried in an oven at $55^{\circ} \mathrm{C}$ [54] for another $48 \mathrm{~h}$. After being cooled on a metal plate, the dried specimen was transferred to a mortar and grinded for avoiding particle clusters. Then, the grinded bentonite powder was suction-controlled to target suction $\left(\mathrm{CaCl}_{2}, 139 \mathrm{MPa}\right)$ using the vapor phase method at a room temperature of $20^{\circ} \mathrm{C}$. After the equilibrium was reached, the amended bentonite powder was compacted into
TABLE 1: Basic properties of the GMZ bentonite.

\begin{tabular}{lcc}
\hline Property & Description & References \\
\hline $\begin{array}{l}\text { Specific gravity of } \\
\text { soil grain }\end{array}$ & 2.66 & Wen [50, 51] \\
$\mathrm{pH}$ & $8.68-9.86$ & Wen [50, 51] \\
$\begin{array}{l}\text { Liquid limit (\%) } \\
\text { Plastic limit (\%) }\end{array}$ & 276 & Ye et al. [14] \\
$\begin{array}{l}\text { Total specific surface } \\
\left.\text { area (m }{ }^{2} / \mathrm{g}\right)\end{array}$ & 37 & Ye et al. [14] \\
$\begin{array}{l}\text { Cation exchange } \\
\text { capacity (mmol/100 g) }\end{array}$ & 570 & Ye et al. [14] \\
& 77.06 & Wen [50, 51] \\
$\begin{array}{l}\text { Exchangeable cation } \\
\text { (mmol/100 g) }\end{array}$ & $\mathrm{E}\left(\mathrm{Na}^{+}\right): 37.52$ & \\
& $\mathrm{E}\left(1 / 2 \mathrm{Cg}^{2+}\right): 23.18$ & Wen [50, 51] \\
& $\mathrm{E}\left(\mathrm{K}^{+}\right): 0.55$ & \\
& Montmorillonite $(75.4 \%)$ & \\
Main minerals & Quartz $(11.7 \%)$ & Wen [50, 51] \\
& Feldspar $(4.3 \%)$ & \\
\hline
\end{tabular}

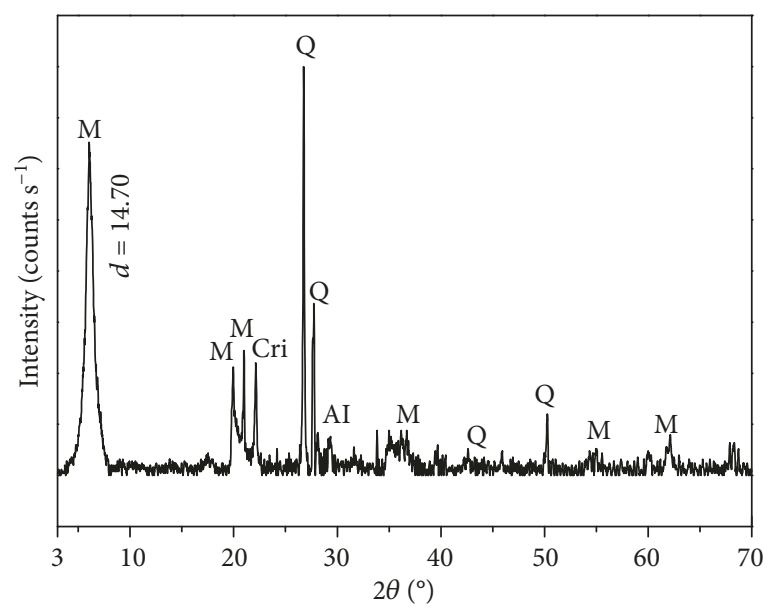

FIgURE 2: XRD pattern for GMZ bentonite powder (M: montmorillonite; Cri: cristobalite; Q: quartz; Al: albite) [52].

cylindrical specimen with a constant speed at $0.1 \mathrm{~mm} / \mathrm{min}$ to a target dimension of $6 \mathrm{~mm}$ in height, a diameter of $20 \mathrm{~mm}$, and a dry density of $1.70 \mathrm{Mg} / \mathrm{m}^{3}$. The specifications of the compacted specimens used in this work are listed in Table 2.

It should be noted that, as the total salt quantity in the specimen is kept constant during the wetting/drying processes, the current salt concentration $c$ of the pore fluid can be determined based on an assumption that there were no chemical interactions between fluid phase and solid phase [55]:

$$
c=\frac{w_{0} c_{0}}{w}
$$

where $w_{0}$ is the target water content $(20 \%), c_{0}$ is the concentration of salt solutions $(0.5 \mathrm{~mol} / \mathrm{L}, 1.0 \mathrm{~mol} / \mathrm{L}$, 
TABle 2: Specifications of the compacted specimens with $\mathrm{NaCl}$ solution.

\begin{tabular}{lccc}
\hline Specimen & $\begin{array}{c}\text { Salt }(\mathrm{NaCl}) / \text { bentonite } \\
\text { ratio } \\
R_{\mathrm{s}}(\mathrm{mmol} / \mathrm{g})\end{array}$ & $\begin{array}{c}\text { Dry density } \\
\left(\mathrm{Mg} / \mathrm{m}^{3}\right)\end{array}$ & $\begin{array}{c}\text { Total suction } \\
(\mathrm{MPa})\end{array}$ \\
\hline$S_{0}$ & 0 & 1.70 & 139 \\
$S_{1}$ & 0.101 & 1.70 & 139 \\
$S_{2}$ & 0.204 & 1.70 & 139 \\
$S_{3}$ & 0.310 & 1.70 & 139 \\
\hline
\end{tabular}

and $1.5 \mathrm{~mol} / \mathrm{L}$ ) used for the preparation of amended GMZ bentonite powder, and $w$ is the current water content.

\subsection{Methodology}

2.2.1. Suction Control. In this work, the vapor phase technique was employed for suction control (Figure 3), in which total suction was applied. For application of the vapor phase method, the confined compacted GMZ bentonite specimens were placed in a desiccator, which was filled with a target saturated salt solution. Saturated salt solutions and their corresponding controlling suctions are listed in Table $3[56,57]$. The specimen was regularly weighted until the equilibrium was reached. For each given suction, this process took about 2 to 4 weeks.

The wetting course from $139 \mathrm{MPa}$ to $4.2 \mathrm{MPa}$, including 6 suctions listed in Table 3, was followed for each of the 4 specimens listed in Table 2.

2.2.2. Determination of Water Content. The gravimetric water content $w$ of each specimen was measured by drying for $24 \mathrm{~h}$ at $105^{\circ} \mathrm{C}$ in an oven. Based on this, the corresponding volumetric water content $\theta_{\mathrm{w}}$ can be calculated by [40]

$$
\theta_{\mathrm{w}}=\frac{S w G_{\mathrm{s}}}{S+w G_{\mathrm{s}}},
$$

where $S$ is the degree of saturation and $G_{\mathrm{s}}$ is the relative density $\left(G_{\mathrm{s}}=2.66\right.$ in Table 1$)$.

For determination of the influence of pore fluid chemistry on the saturated ("zero air voids" [40]) water content, $\theta_{\text {s }}$ was assumed as the saturated water content corresponding to matric suction equal to 0 [31]. Following this aspect, specimens with different salt contents were inundated in distilled water. This saturation process lasted about 6-8 days [58]. After the equilibrium was reached, water content $w$ was measured and the saturated volumetric water content $\theta_{\mathrm{s}}$ was calculated using equation (2).

\section{Results}

3.1. Influence of Salt Content on SWRC. The measured SWRCs of confined compacted GMZ bentonite with different salt contents in wetting path are shown in Figure 4.

According to Figure 4, the measured volumetric water content decreases with the increasing suction. For a given suction, the measured water content of specimens increases as the salt content (or pore fluid concentration) increases.
Furthermore, the influencing rate depends on suction. For lower suctions (lower than $38 \mathrm{MPa}$ ), water retention capacity increases with the increase in salt content, while for higher suctions (higher than $38 \mathrm{MPa}$ ), the influence was negligible. It can be inferred that, for low suctions, the high saturation induced an increase in macropore size $[38,59]$, which was further enhanced due to the increase in salt content. However, this phenomenon was faded as the suction increased, which may attribute to the decrease in water content.

3.2. Influence of Pore Fluid Concentration on Saturated Water Content $\theta_{\text {s. }}$. For the confined compacted GMZ bentonite at a dry density of $1.7 \mathrm{Mg} / \mathrm{m}^{3}$ with different salt contents, measured saturated water content $\theta_{\mathrm{s}}$ versus pore fluid concentration $\left(c_{\mathrm{s}}\right)$ is presented in Figure 5.

It is obvious that water content $\theta_{\mathrm{s}}$ increases with the increase in pore fluid salt concentration, while the increasing rate decreases as the salt concentration increases and becomes stable for the fluid salt concentration higher than $0.735 \mathrm{~mol} / \mathrm{L}$. Possible explanations to pore fluid chemistry effects on the water content $\theta_{\mathrm{s}}$ could be that the increase in the concentration of pore fluid results in the decrease in the diffuse double layer of bentonite [60]; i.e., a high water salinity of the pore fluid could induce the contraction of clay aggregates and thus increase the void volume between the aggregates (interaggregate or macropores) [59].

\section{A Modified SWRC Model with Consideration of Salt Solution Effects}

4.1. Equation for SWRC. As mentioned before, due to difficulties and labor costs for measuring SWRC, many empirical models for SWRC have been developed. Actually, among all the models available, the commonly used ones are those proposed by van Genuchten [29], Fredlund and Xing [28], and Houston et al. [61], while the Fredlund and Xing model appears to be the most appropriate one for fitting the experimental data [62].

The Fredlund and Xing model [28] can be expressed as follows:

$$
\theta=C(\psi) \times \frac{\theta_{s}}{\left\{\ln \left[e+(\psi / a)^{n}\right]\right\}^{m}},
$$

where $\psi$ is the suction and $C(\psi)$ is a correction function that can be defined as

$$
C(\psi)=\left[1-\frac{\ln \left(1+\psi / \psi_{\mathrm{r}}\right)}{1+1000 / \psi_{\mathrm{r}}}\right],
$$

where $\psi_{\mathrm{r}}$ is the suction corresponding to the residual water content.

Parameter $a$, a suction that is closely related with the SWRC's inflection point, can be considered as the air entry value when parameter $m$ is small, even if the parameter $a$ value is usually bigger than that of air entry [28]. Parameter $a$ makes the curve towards the region of higher soil suction 


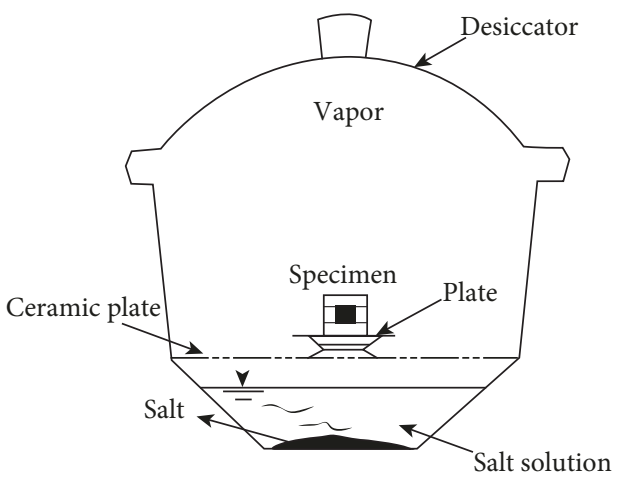

(a)

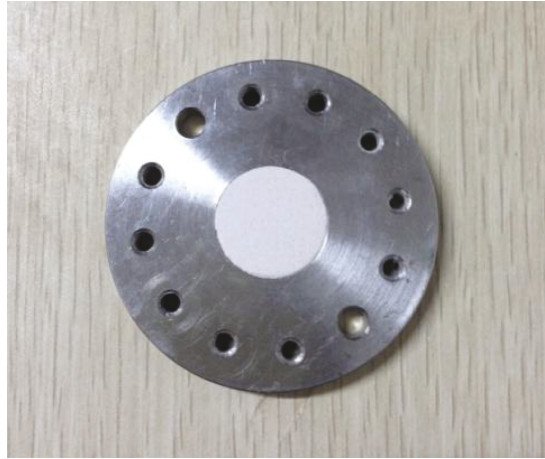

(b)

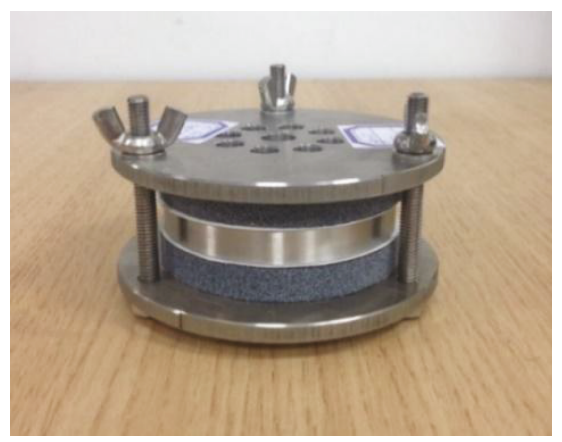

(c)

FIGURE 3: Schematic setup for the vapor-phase technique (a) desiccator, (b) specimen, and (c) cell.

TABLE 3: Saturated salt solutions and corresponding suctions $\left(20^{\circ} \mathrm{C}\right)$ $[56,57]$.

\begin{tabular}{lc}
\hline Saturated salt solutions & Total suction $(\mathrm{MPa})$ \\
\hline $\mathrm{K}_{2} \mathrm{SO}_{4}$ & 4.2 \\
$\mathrm{ZnSO}_{4}$ & 12.6 \\
$(\mathrm{NH} 4)_{2} \mathrm{SO}_{4}$ & 24.9 \\
$\mathrm{NaCl}$ & 38 \\
$\mathrm{Mg}\left(\mathrm{NO}_{3}\right)_{2}$ & 82 \\
$\mathrm{CaCl}_{2}$ & 139 \\
\hline
\end{tabular}

as its value increases but has no effect on the overall shape of curves [63]. Parameter $m$, which represents the curve asymmetry around the inflection point, is associated with the residual water content. Parameter $n$ affects the slope of SWRC in the desaturation region. The value of $n$ is associated with pore size distribution, which always shows a positive relationship with the uniformity of the pore sizes in the soil $[63,64]$.

\subsection{A Modified SWRC Model with Consideration of Pore Fluid Concentration Effects}

\subsubsection{Determination of Parameters}

(1) Determination of $\theta_{s}$ with Consideration of Pore Fluid Concentration. To consider the pore fluid concentration effects in equation (3), influence of the pore fluid concentration on the saturated water content $\theta_{\mathrm{s}}$ should be included.
It can be observed from Figure 5 that the measured relationship between the water content $\left(\theta_{\mathrm{s}}\right)$ and the pore fluid concentration $\left(c_{\mathrm{s}}\right)$ looks like an asymptotic line. Therefore, a second-order equation (5) was proposed for fitting the saturated water content $\theta_{\mathrm{s}}$ and pore fluid concentration $c_{\mathrm{s}}$ at the saturated state.

$$
\frac{d \theta_{s}}{d c}=k\left(\theta_{\max }-\theta_{s}\right)^{2}
$$

Integrating equation (5) from $c=0, \theta_{0}$ to $c$ and $\theta_{c}$ (where $\theta_{0}=0.3984$, which was calculated by equation (2) using the gravimetric water content $w$ measured at matric suction $0 \mathrm{MPa}$, and $\theta_{\mathrm{c}}=\theta_{\text {max }}$, which was assumed as the maximum value of volumetric water content of specimens tested), yields,

$$
\theta_{\mathrm{s}}(c)=\theta_{\max }-\frac{\theta_{\max }-0.3984}{k c_{\mathrm{s}}\left(\theta_{\max }-0.3984\right)+1},
$$

where $c_{s}$ is the pore fluid concentration of chemical components corresponding to matric suction $\psi_{\mathrm{m}}=0 \mathrm{MPa}, k$ is a coefficient related to salt concentration, and $\theta_{s}(c)$ is the saturated water content at the current chemical concentration. The values of $c_{\mathrm{s}}$ and saturated water content $\theta_{\mathrm{s}}$ can be calculated using equations (2) and (6).

With salt concentrations $0.01,0.384,0.735$, and $2.0 \mathrm{~mol} / \mathrm{L}$ and the corresponding measured saturated water contents in 


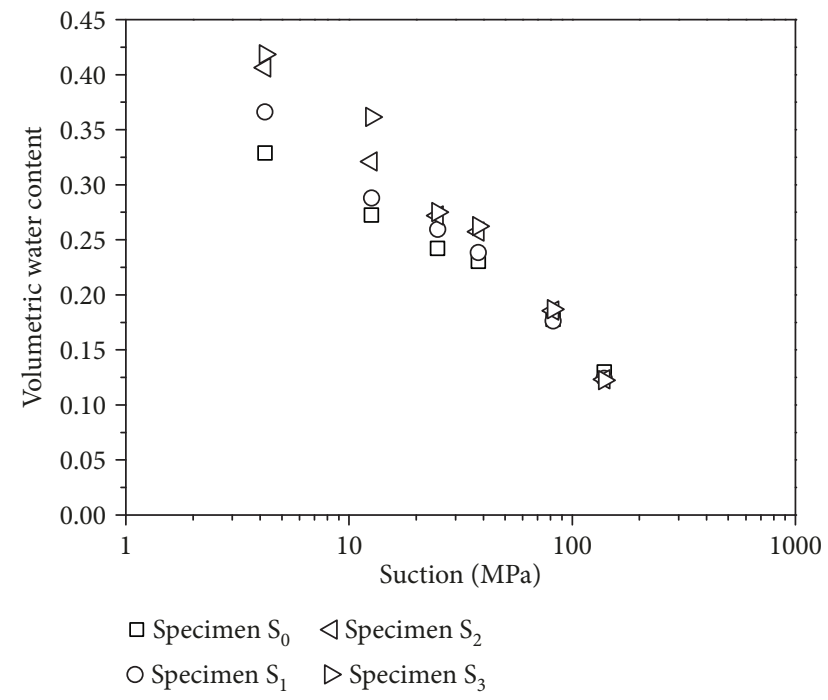

Figure 4: SWRCs of compacted GMZ bentonite specimens with different salt contents.

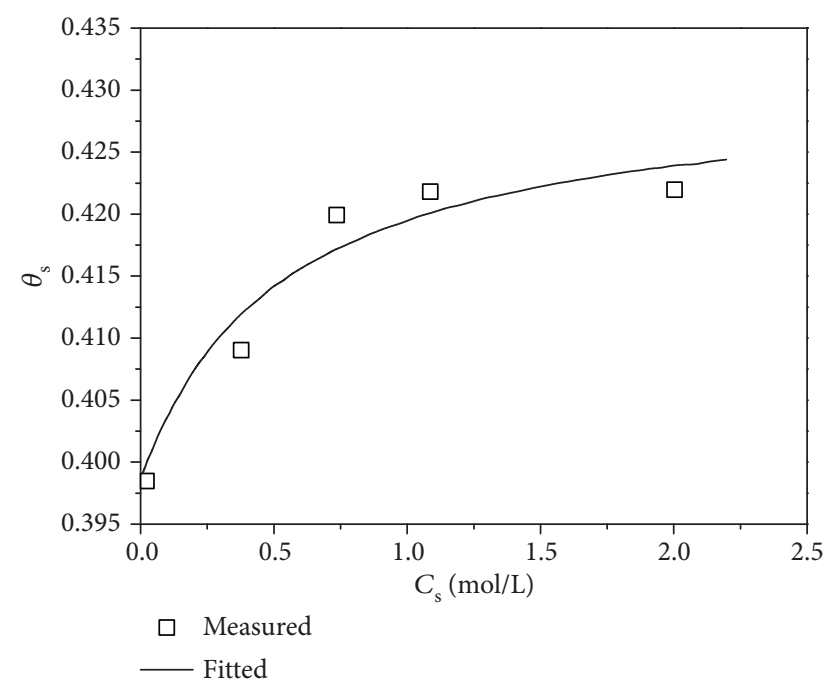

Figure 5: Water content $\theta_{\mathrm{s}}$ versus pore fluid concentration $c_{\mathrm{s}}$ at a saturated state.

Figure $5, k$ and $\theta_{\max }$ can be fitted using equation (6) and substituted back into equation (6), which gives

$$
\theta_{\mathrm{s}}(c)=0.4305-\frac{0.0321}{1.894 \times c_{\mathrm{s}}+1}
$$

With equation (7), the relationship between $\theta_{\mathrm{s}}$ and $c_{\mathrm{s}}$ can be depicted in Figure 5. Figure 5 indicates that the secondorder equation (5) proposed in this work can satisfactorily describe the saturated water content with consideration of pore fluid chemistry.

(2) Determination of a with Consideration of Pore Fluid Concentration. To consider the pore fluid concentration effects in equation (3), the effects of the pore fluid concentration on the air entry value (parameter $a$ ) should be analyzed as well.

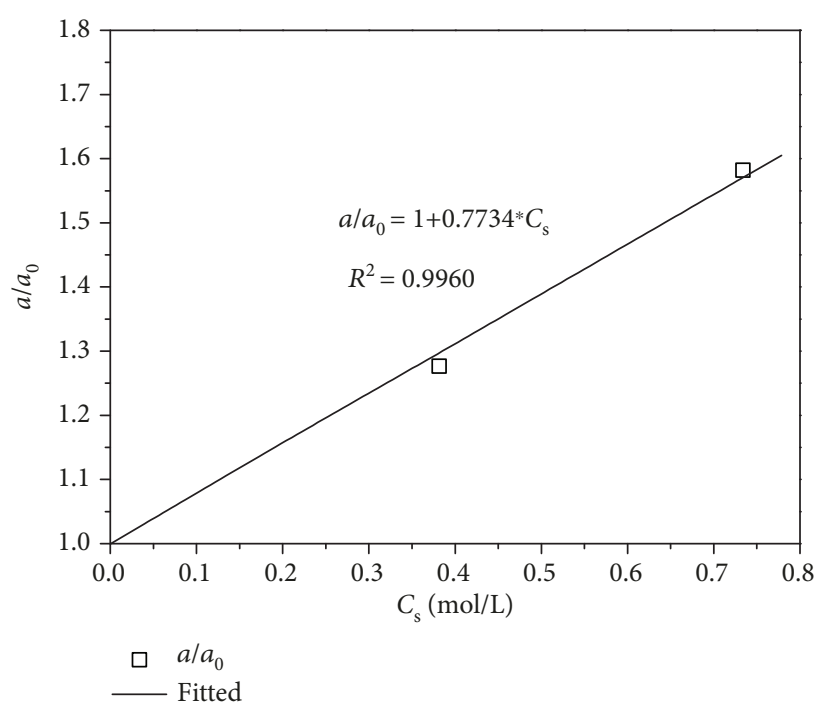

FIGURE 6: Relationship between the air entry value-related parameter and the pore fluid concentration.

In this respect, Karagunduz et al. [65] once proposed an approximate linear relationship (equation (8)) between the air entry value-related parameter $a$ and the chemical concentration of the pore fluid.

$$
a(c)=\left(1+\beta c_{\mathrm{s}}\right) a_{0}
$$

where $c_{\mathrm{s}}$ is the pore fluid concentration corresponding to matric suction $\psi_{\mathrm{m}}=0 \mathrm{MPa}, \beta$ is a concentration-related coefficient, and $a_{0}$ is the air entry value-related parameter of specimen hydrated with distilled water.

The fitted relationship between the air entry value-related parameter $a$ and the pore fluid concentration for confined compacted GMZ bentonite is presented in Figure 6. Results show that a very good linear relationship can be observed.

With the relationship between the air entry value-related parameter and the pore fluid concentration in Figure 6, parameter $\beta$ can be fitted using equation (8) with a value of 0.7734 for confined compacted GMZ bentonite.

(3) Determination of $n$ with Consideration of Pore Fluid Concentration. In equation (3), $n$ reflects the slope of the SWRC in the desaturation zone [30], which is determined by the pore size distribution of the specimen.

The concentration of infiltration pore fluid will influence pore size distribution, which results in variation of the $n$ value and the shape of SWRC. This phenomenon has been observed and traditionally explained by means of the diffuse double-layer theory (DDL) [66]. Thickness of the diffuse double layer decreases with increasing concentration of electrolytes or their valence in the pore fluid, which results in the contraction of clay aggregates locally and the corresponding increase in connecting pores in the clay. Therefore, although the use of hypotheses assumed by the double-layer theory is still restrictive and merely for engineering purposes [60, 67], it is still 


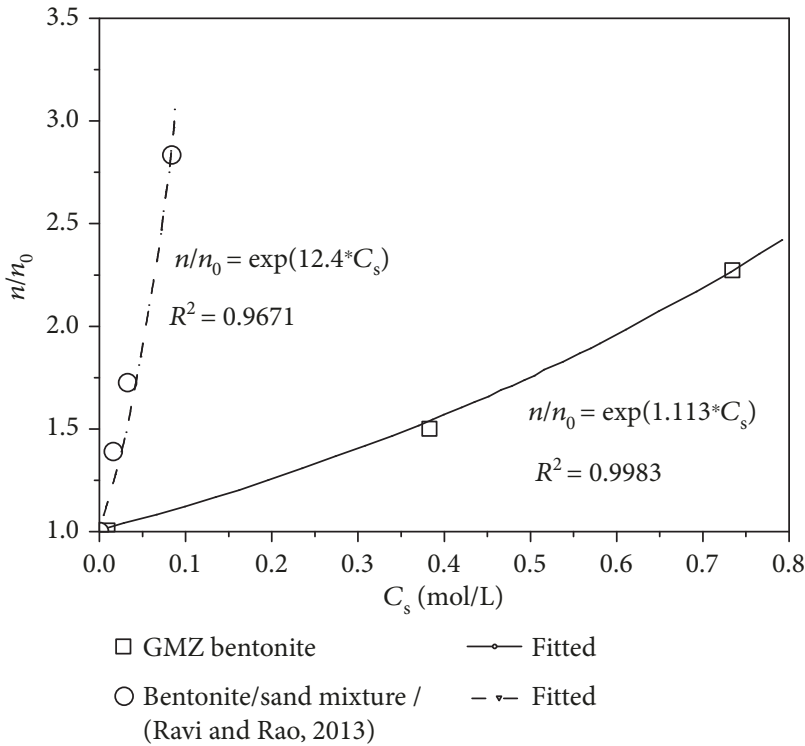

FIGURE 7: Relationship between the slope value of SWRCs and the pore fluid concentration.

helpful and reasonable to interpret most of the relations between pore fluid chemistry and macroscopic behaviour of clays $[41,68]$.

The influence of pore fluid concentration on water retention properties of clay has succeeded to attract sufficient attention by researchers $[38,39]$. Among the literatures, the work of Ravi and Rao [39] provides a noteworthy contribution in this area. The measurement of SWRCs of bentonite/sand mixture specimens with different dry densities, respectively, in the distilled water group and $\mathrm{NaCl}$ solution group, was reported in the literature. Results showed that the concentration of infiltration pore fluid has a significant effect on SWRCs. On the basis of the measured data, the relationship between the slope value $n / n_{0}$ of SWRCs of bentonite/sand-mixed specimens and the corresponding concentrations of pore fluid was fitted and depicted, as shown in Figure 7.

Based on the fitted results in Figure 7, the relationship between the slope values $n$ and the concentrations of pore fluid could be assumed as

$$
n(c)=\exp \left(\xi c_{s}\right) n_{0}
$$

where $\xi$ is a concentration-related coefficient to be fitted, $c_{\mathrm{s}}$ is the pore fluid concentration corresponding to matric suction $\psi_{\mathrm{m}}=0 \mathrm{MPa}$, and $n_{0}$ is the slope value of SWRC of specimens hydrated with distilled water.

With SWRCs of confined compacted GMZ bentonite specimens with dry density of $1.7 \mathrm{Mg} / \mathrm{m}^{3}$ tested using distilled water and different concentrations of $\mathrm{NaCl}$ solutions in this work, the relationship between the slope values of SWRCs and the corresponding pore fluid concentrations is shown in Figure 7. Parameter $\xi$ was fitted with a value of 1.113. Therefore, the relationship between the slope values $n$ of SWRCs and pore fluid concentrations for confined compacted GMZ bentonite can be expressed as

$$
n(c)=\exp \left(1.113 c_{\mathrm{s}}\right) n_{0}
$$

It can be observed that the value of the concentrationrelated parameter of $1.5 \mathrm{Mg} / \mathrm{m}^{3} \quad(\xi=12.4)$ bentonite/sand mixture specimens is larger than that of $1.7 \mathrm{Mg} / \mathrm{m}^{3} \mathrm{GMZ}$ bentonite specimen $(\xi=1.113)$. This observation indicates that the influence of pore fluid concentrations on the slope values $n$ of SWRCs depends on dry density. A possible explanation to this observation could be that the specimens with lower dry density have more pore space for pore fluid intrusion, which enhanced the increase in the interaggregate or macropores induced by the contraction of clay aggregates [59]. However, for compacted bentonite with higher dry density, less pore-fluid intrusion is likely to be insufficient to form enough DDL in a small interlayer space $[37,69]$.

Comparison results indicate that the proposed exponential function (equation (9)) can satisfactorily describe the relationship of the slope values $n$ of SWRCs and the pore fluid concentrations.

4.2.2. A Modified SWRC Model with Consideration of Pore Fluid Chemistry. Substituting equations (6), (8), and (10) into equation (3), equation (11) can be obtained.

$$
\theta=C(\psi) \times \frac{\theta_{s}(c)}{\left\{\ln \left[e+(\psi / a(c))^{n(c)}\right]\right\}^{m}},
$$

where $C(\Psi), \theta_{s}(c), a(c)$, and $n(c)$ can be calculated using equations (4), (6), (8), and (10), respectively.

It should be noted that, considering that the influence of the pore fluid concentration on the residual water content of compacted clays is insignificant (Figure 4), the influence of pore fluid chemistry on parameter $m$ is safely neglected in this model.

Deduced from the Fredlund and Xing [28] SWRC equation, equation (11) is the modified model that can be used for predicting the SWRCs of confined compacted GMZ bentonite with consideration of pore fluid chemistry.

It should be noted that, in equation (11), for calculation of $C(\psi)$ using equation (4), the residual suction $\psi_{\mathrm{r}}$ should be determined. Commonly, $\psi_{\mathrm{r}}$ was practically determined or assumed that the maximum suction is applied, which is corresponding to a lower enough water content [30]. For instance, Phayak [70] chose the suction corresponding to $3.51 \%$ water content as the residual suction $\psi_{\mathrm{r}}$. Wan [30] assumed the maximum suction of $309 \mathrm{MPa}$ applied at $20^{\circ} \mathrm{C}$ to be the residual suction $\psi_{\mathrm{r}}$ corresponding to a water content of about 5\% for compacted GMZ bentonite. In this study, the maximum suction of $139 \mathrm{MPa}$ applied is assumed to be the residual suction $\psi_{\mathrm{r}}$ of GMZ bentonite, which is corresponding to a water content around $8 \%$.

4.2.3. Verification. Figure 8 shows the measured SWRCs of the compacted GMZ bentonite hydrated with different salt 


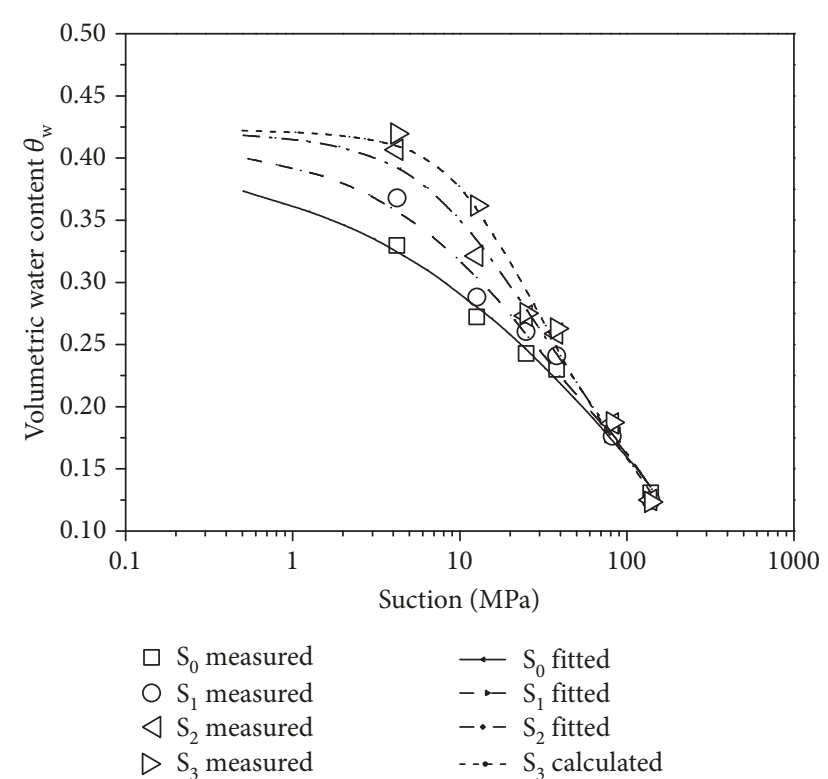

FIGURE 8: Relationship between water content and suction of the compacted GMZ bentonite.

concentrations $\left(S_{0}, S_{1}, S_{2}\right.$, and $\left.S_{3}\right)$ and distilled water. Based on the measured SWRCs of $S_{0}, S_{1}$, and $S_{2}$, as well as equations (1), (2), and (11), parameters $\theta_{\max }, k, \beta$, and $\xi$ in equation (11) for the compacted GMZ bentonite with $1.7 \mathrm{Mg} / \mathrm{m}^{3}$ dry density can be determined: $\theta_{\max }=0.4305$, $k=59.01, \beta=0.7734$, and $\xi=1.113$. Substituting $\theta_{\max }, k$, $\beta$, and $\xi$ into equation (11) gives

$$
\theta=C(\psi) \times \frac{\theta_{s}(c)}{\left\{\ln \left[e+(\psi / a(c))^{n(c)}\right]\right\}^{m}},
$$

where

$$
\begin{aligned}
& \theta_{\mathrm{s}}(c)=0.4305-\frac{0.0321}{1.894 \times c_{\mathrm{s}}+1}, \\
& a(c)=\left(1+0.7734 \times c_{\mathrm{s}}\right) \times 6.684, \\
& n(c)=\exp \left(1.113 \times c_{\mathrm{s}}\right) \times 0.593
\end{aligned}
$$

Equation (12) is the modified model for describing the SWRCs of the confined compacted GMZ bentonite taking account of the pore fluid concentration.

With equation (12), the SWRC of specimen $S_{3}$ was calculated. According to the contrast between the calculated results and measurement data (Figure 8), the proposed model can well describe the effects of the pore fluid chemistry process on the SWRCs of confined compacted GMZ bentonite.

\section{Conclusions}

In this work, the SWRCs of confined compacted GMZ bentonite with different salt contents were attained by a series of suction-controlled tests. The effects of pore fluid chemistry on the water retention properties of GMZ bentonite were analyzed. A modified model considering the pore fluid chemistry effects for describing the SWRCs of confined compacted GMZ bentonite was proposed and verified. The main conclusions can be drawn as follows.

For the compacted GMZ bentonite, the effect of pore fluid chemistry on the water retention properties depends on suction. For a given suction, the measured water content of specimens increases with the increase in pore fluid concentration. Furthermore, the influencing rate depends on suction.

With the Fredlund and Xing equation, parameters including the air entry value-related parameter $a$, the saturated water content $\theta_{\text {s }}$, and the slope value $n$ of SWRCs were determined with consideration of the influence of the pore fluid concentration. Based on these, a modified model with consideration of pore fluid chemistry effects was proposed to describe the SWRCs of the compacted GMZ bentonite. The contrast of the calculated results and the experimental data demonstrates that the modified model can satisfactorily describe the water retention properties of compacted GMZ bentonite with consideration of pore fluid chemistry effects.

It should be noted that the proposed model only verified with test results of confined compacted GMZ bentonite. Further investigations should be done in the coming work for extending its applications to related geomaterials.

\section{Data Availability}

The data used to support the findings of this study are available from the corresponding author upon request.

\section{Conflicts of Interest}

The authors declare that they have no conflicts of interest.

\section{Acknowledgments}

The authors are grateful to the National Natural Science Foundation of China (Project Nos. 41807253, 41672271, and 41527801) for the financial support. The authors also wish to acknowledge the support of the European Commission via the Marie Curie IRSES project GREAT_-Geotechnical and geological Responses to climate change: Exchanging Approaches and Technologies on a world-wide scale (FP7PEOPLE-2013-IRSES-612665). The authors are also grateful to the Research Fund Program of the Key Laboratory of Geotechnical and Underground Engineering (Tongji University), Ministry of Education (Project No. KLE-TJGE-B1803).

\section{References}

[1] ENRESA, Full-Scale Engineered Barriers Experiment for Deep Geological Repository for High-Level Radioactive Waste in Crystalline Rock (FEBEX Project), EUR 19147, Nuclear Science and Technology Series, Luxembourg, 2000.

[2] Y. He, Y. G. Chen, and W. M. Ye, "Equilibrium, kinetic, and thermodynamic studies of adsorption of $\mathrm{Sr}$ (II) from aqueous solution onto GMZ bentonite," Environmental Earth Sciences, vol. 75 , no. 9 , p. $807,2016$. 
[3] JNC, H12 Project to Establish Technical Basis for HLW Disposal in Japan, Support Report 2, Japan Nuclear Cycle Development Institute, 1999.

[4] M. J. Kim, S. R. Lee, J. S. Jeon, and S. Yoon, "Sensitivity analysis of bentonite buffer peak temperature in a high-level waste repository," Annals of Nuclear Energy, vol. 123, pp. 190-199, 2019.

[5] D. Marcial, P. Delage, and Y. J. Cui, "On the high stress compression of bentonites," Canadian Geotechnical Journal, vol. 39, no. 4, pp. 812-820, 2002.

[6] P. L. Martín, J. M. Barcala, and F. Huertas, "Large-scale and long-term coupled thermo-hydro-mechanic experiments with bentonite: the FEBEX mock-up test," Journal of Iberian Geology, vol. 32, no. 2, pp. 259-282, 2006.

[7] R. Pusch and R. Weston, "Superior techniques for disposal of highly radioactive waste (HLW)," Environmental Earth Sciences, vol. 73, no. 9, pp. 5219-5231, 2015.

[8] S. M. Rao and K. Ravi, "Influence of initial degree of saturation on swell pressures of compacted Barmer bentonite specimens," Annals of Nuclear Energy, vol. 80, pp. 303311, 2015.

[9] SKB, "SR-97 Waste, repository design and sites," SKB Technical Report TR-99-08, Stockholm, Sweden, 1999.

[10] A. Dutt, M. S. Saini, T. N. Singh, A. K. Verma, and R. K. Bajpai, "Analysis of thermo-hydrologic-mechanical impact of repository for high-level radioactive waste in clay host formation: an Indian reference disposal system," Environmental Earth Sciences, vol. 66, no. 8, pp. 2327-2341, 2012.

[11] A. P. Fraser Harris, C. I. McDermott, O. Kolditz, and R. S. Haszeldine, "Modelling groundwater flow changes due to thermal effects of radioactive waste disposal at a hypothetical repository site near Sellafield, UK," Environmental Earth Sciences, vol. 74, no. 2, pp. 1589-1602, 2015.

[12] M. Xie, S. Bauer, O. Kolditz, T. Nowak, and H. Shao, "Numerical simulation of reactive processes in an experiment with partially saturated bentonite," Journal of Contaminant Hydrology, vol. 83, no. 1-2, pp. 122-147, 2006.

[13] J. Kasbohm, R. Pusch, L. Nguyen-Thanh, and T. Hoang-Minh, "Lab-scale performance of selected expandable clays under HLW repository conditions," Environmental Earth Sciences, vol. 69, no. 8, pp. 2569-2579, 2013.

[14] W. M. Ye, M. Wan, B. Chen, Y. G. Chen, Y. J. Cui, and J. Wang, "Temperature effects on the unsaturated permeability of the densely compacted GMZ01 bentonite under confined conditions," Engineering Geology, vol. 126, pp. 1-7, 2012.

[15] W. M. Ye, M. Wan, B. Chen, Y. G. Chen, Y. J. Cui, and J. Wang, "Temperature effects on the swelling pressure and saturated hydraulic conductivity of the compacted GMZ01 bentonite," Environmental Earth Sciences, vol. 68, no. 1, pp. 281-288, 2013.

[16] P. J. Cleall, T. A. Melhuish, and H. R. Thomas, "Modelling the three-dimensional behaviour of a prototype nuclear waste repository," Engineering Geology, vol. 85, no. 1-2, pp. 212220, 2006.

[17] A. Lloret and M. V. Villar, "Advances on the knowledge of the thermo-hydro-mechanical behaviour of heavily compacted "FEBEX" bentonite," Physics and Chemistry of the Earth, Parts $A / B / C$, vol. 32, no. 8-14, pp. 701-715, 2007.

[18] J. Rutqvist, D. Barr, J. T. Birkholzer et al., "Results from an international simulation study on coupled thermal, hydrological, and mechanical processes near geological nuclear waste repositories," Nuclear Technology, vol. 163, no. 1, pp. 101109, 2008.

[19] L. H. Johnson, D. M. LeNeveu, D. W. Shoesmith et al., The Disposal of Canada's Nuclear Fuel Waste: the Vault Model for Postclosure Assessment, AECL Research Document No. AECL10714, COG-93-8, Atomic Energy of Canada Limited, Pinawa, Manitoba, Canada, 1994.

[20] R. Senger, P. Marschall, and S. Finsterle, "Investigation of twophase flow phenomena associated with corrosion in an SF/HLW repository in Opalinus Clay, Switzerland," Physics and Chemistry of the Earth, Parts $A / B / C$, vol. 33, pp. S317S326, 2008.

[21] S. García-García, M. Jonsson, and S. Wold, "Temperature effect on the stability of bentonite colloids in water," Journal of Colloid and Interface Science, vol. 298, no. 2, pp. 694-705, 2006.

[22] E. Castellanos, M. V. Villar, E. Romero, A. Lloret, and A. Gens, "Chemical impact on the hydro-mechanical behaviour of high-density FEBEX bentonite," Physics and Chemistry of the Earth, Parts A/B/C, vol. 33, pp. S516-S526, 2008.

[23] W. M. Ye, Y. J. Cui, L. X. Qian, and B. Chen, "An experimental study of the water transfer through confined compacted GMZ bentonite," Engineering Geology, vol. 108, no. 3-4, pp. 169176, 2009 .

[24] F. J. Leij, W. B. Russell, and S. M. Lesch, "Closed-form expressions for water retention and conductivity data," Ground Water, vol. 35, no. 5, pp. 848-858, 1997.

[25] M. Tuller and D. Or, "Retention of water in soil and the soil water characteristic curve," Encyclopedia of Soils in the Environment, vol. 4, pp. 278-289, 2004.

[26] A. Hildenbrand, S. Schlömer, and B. M. Krooss, "Gas breakthrough experiments on fine-grained sedimentary rocks," Geofluids, vol. 2, no. 1, 23 pages, 2002.

[27] R. H. Brooks and A. T. Corey, Hydraulic Properties of Porous Media, Hydrol. Pap. 3, Colorado State University, Fort Collins, CO, USA, 1964.

[28] D. G. Fredlund and A. Xing, "Equations for the soil-water characteristic curve," Canadian Geotechnical Journal, vol. 31, no. 4, pp. 521-532, 1994.

[29] M. T. H. van Genuchten, "A closed-form equation for predicting the hydraulic conductivity of unsaturated soils," Soil Science Society of America Journal, vol. 44, no. 5, p. 892, 1980.

[30] M. Wan, Study on Soil-Water Characteristics and Permeability of Highly Compacted GMZ Bentonite with Temperature Control, [Ph.D. Thesis], Tongji University, 2010.

[31] A. Jacinto, M. Villar, R. Gomezespina, and A. Ledesma, "Adaptation of the van Genuchten expression to the effects of temperature and density for compacted bentonites," Applied Clay Science, vol. 42, no. 3-4, pp. 575-582, 2009.

[32] M. V. Villar, R. Gómez-Espina, and A. Lloret, "Experimental investigation into temperature effect on hydro-mechanical behaviours of bentonite," Journal of Rock Mechanics and Geotechnical Engineering, vol. 2, no. 1, pp. 71-78, 2010.

[33] N. Lu and W. J. Likos, Unsaturated Soil Mechanics, Wiley, New York, NY, USA, 2004.

[34] T. M. Thu, H. Rahardjo, and E. C. Leong, "Soil-water characteristic curve and consolidation behavior for a compacted silt," Canadian Geotechnical Journal, vol. 44, no. 3, pp. 266-275, 2007.

[35] T. Thyagaraj and S. M. Rao, "Influence of osmotic suction on the soil-water characteristic curves of compacted expansive 
clay," Journal of Geotechnical and Geoenvironmental Engineering, vol. 136, no. 12, pp. 1695-1702, 2010.

[36] M. V. Villar and A. Lloret, "Influence of temperature on the hydro-mechanical behaviour of a compacted bentonite," Applied Clay Science, vol. 26, no. 1-4, pp. 337-350, 2004.

[37] Y. He, Y.-G. Chen, W.-M. Ye, B. Chen, and Y.-J. Cui, "Influence of salt concentration on volume shrinkage and water retention characteristics of compacted GMZ bentonite," Environmental Earth Sciences, vol. 75, no. 6, p. 535, 2016.

[38] C. Mata, E. Romero, and A. Ledesma, "Hydro-chemical effects on water retention in bentonite-sand mixtures," in Proceeding of the 3rd International Conference on Unsaturated soil, vol. 1, pp. 283-288, Recife, Brazil, 2002.

[39] K. Ravi and S. M. Rao, "Influence of infiltration of sodium chloride solutions on SWCC of compacted bentonite-sand specimens," Geotechnical and Geological Engineering, vol. 31, no. 4, pp. 1291-1303, 2013.

[40] D. G. Fredlund and H. Rahardjo, Soil Mechanics for Unsaturated Soils, Wiley, New York, NY, USA, 1993.

[41] N. Mokni, Deformation and Flow Driven by Osmotic Processes in Porous Materials, [Ph.D. Thesis], Department of Geotechnical Engineering and Geo-science (ETCG) Technical University of Catalunya, UPC, Barcelona, Spain, 2011.

[42] B. Chen, L. X. Qian, W. M. Ye, Y. J. Cui, and J. Wang, "Soil water characteristic curves of Gaomiaozi bentonite," Chinese Journal of Rock Mechanics and Engineering, vol. 25, no. 4, pp. 788-794, 2006.

[43] Y. He, W. M. Ye, Y. G. Chen, B. Chen, B. Ye, and Y. J. Cui, "Influence of pore fluid concentration on water retention properties of compacted GMZ01 bentonite," Applied Clay Science, vol. 129, pp. 131-141, 2016.

[44] W. M. Ye, N. C. Borrell, J. Y. Zhu, B. Chen, and Y. G. Chen, "Advances on the investigation of the hydraulic behavior of compacted GMZ bentonite," Engineering Geology, vol. 169, pp. 41-49, 2014.

[45] W. M. Ye, Y. G. Chen, B. Chen, Q. Wang, and J. Wang, "Advances on the knowledge of the buffer/backfill properties of heavily-compacted GMZ bentonite," Engineering Geology, vol. 116, no. 1-2, pp. 12-20, 2010.

[46] W. M. Ye, M. Wan, B. Chen, Y. G. Chen, Y. J. Cui, and J. Wang, "Effect of temperature on soil-water characteristics and hysteresis of compacted Gaomiaozi bentonite," Journal of Central South University of Technology, vol. 16, no. 5, pp. 821-826, 2009.

[47] M. Sanchez, Thermo-Hydro-Mechanical Coupled Analyses in Low Permeability Media, [Ph.D. Thesis], Universitat Politecnica de Catalunya, Barcelona, Spain, 2004.

[48] Y. H. Guo, T. X. Yang, and S. F. Liu, "Hydrogeological characteristics of Beishan preselected area, Gansu province for China's high-level radioactive waste repository," Uranium Geology, vol. 17, no. 3, pp. 184-189, 2001.

[49] J. Wang, L. Chen, R. Su, and X. Zhao, "The Beishan underground research laboratory for geological disposal of highlevel radioactive waste in China: planning, site selection, site characterization and in situ tests," Journal of Rock Mechanics and Geotechnical Engineering, vol. 10, no. 3, pp. 411-435, 2018.

[50] Z. J. Wen, "Selection and basic properties of China's buffer materials for high level radioactive waste repository," Acta Petrologica et Mineralogica, vol. 24, no. 6, pp. 583-586, 2005.
[51] Z. J. Wen, "Selection and basic properties of the buffer material for high-level radioactive waste repository in China," Acta Geologica Sinica - English Edition, vol. 82, no. 5, pp. 10501055, 2008.

[52] Y. He, W. M. Ye, Y. G. Chen, and Y. J. Cui, "Effects of K ${ }^{+}$solutions on swelling behavior of compacted GMZ bentonite," Engineering Geology, vol. 249, pp. 241-248, 2019.

[53] X. P. Nguyen, Y. J. Cui, A. M. Tang, Y. F. Deng, X. L. Li, and L. Wouters, "Effects of pore water chemical composition on the hydro-mechanical behavior of natural stiff clays," Engineering Geology, vol. 166, pp. 52-64, 2013.

[54] O. Karnland, S. Olsson, U. Nilsson, and P. Sellin, "Experimentally determined swelling pressures and geochemical interactions of compacted Wyoming bentonite with highly alkaline solutions," Physics and Chemistry of the Earth, Parts $A / B / C$, vol. 32, no. 1-7, pp. 275-286, 2007.

[55] C. Mata, Hydraulic Behavior of Bentonite Based Mixtures in Engineered Barriers: the Backfill and Plug Test at the ÄSPÖ HRL (Sweden), [Ph.D. Thesis], Technical University of Catalonia Department of Geotechnical Engineering and Geosciences School of Civil Engineering, Barcelona, Spain, 2003.

[56] P. Delage, M. D. Howat, and Y. J. Cui, "The relationship between suction and swelling properties in a heavily compacted unsaturated clay," Engineering Geology, vol. 50, no. 12, pp. 31-48, 1998.

[57] A. M. Tang and Y. J. Cui, "Controlling suction by the vapour equilibrium technique at different temperatures and its application in determining the water retention properties of MX80 clay," Canadian Geotechnical Journal, vol. 42, no. 1, pp. 287-296, 2005.

[58] C. M. Zhu, W. M. Ye, Y. G. Chen, B. Chen, and Y. J. Cui, "Influence of salt solutions on the swelling pressure and hydraulic conductivity of compacted GMZ01 bentonite," Engineering Geology, vol. 166, pp. 74-80, 2013.

[59] G. Musso, E. Romero, and G. D. Vecchia, "Double-structure effects on the chemo-hydro-mechanical behaviour of a compacted active clay," Géotechnique, vol. 63, no. 3, pp. 206-220, 2013.

[60] T. A. Hueckel, "Water-mineral interaction in hygromechanics of clays exposed to environmental loads: a mixture theory approach," Canadian Geotechnical Journal, vol. 29, no. 6, pp. 1071-1086, 1992.

[61] W. N. Houston, H. B. Dye, C. E. Zapata, Y. Y. Perera, and A. Harraz, "Determination of SWCC using one point suction measurement and standard curves," in Geotechnical Special Publication, pp. 1482-1493, Reston, VA, USA, 147 edition, 2006.

[62] S. Nam, M. Gutierrez, P. Diplas et al., "Comparison of testing techniques and models for establishing the SWCC of riverbank soils," Engineering Geology, vol. 110, no. 1-2, pp. 1-10, 2010.

[63] G. L. S. Babu, J. Peter, M. Mukesh, and E. Gartung, "Significance of soil suction and soil water characteristic curve parameters," Geotechnical Testing Journal, vol. 28, no. 1, pp. 102-107, 2005.

[64] W. C. Sillers, D. G. Fredlund, and H. Rahardjo, "Mathematical attributes of some soil-water characteristic curve models," in Unsaturated Soil Concepts and Their Application in Geotechnical Practice, pp. 243-283, Springer, Dordrecht, Netherlands, 2001.

[65] A. Karagunduz, K. D. Pennell, and M. H. Young, "Influence of a nonionic surfactant on the water retention properties of 
unsaturated soils," Soil Science Society of America Journal, vol. 65, no. 5, pp. 1392-1399, 2001.

[66] J. K. Mitchell, Fundamentals of Soil Behavior, John Wiley and Sons, New York, NY, USA, 2nd edition, 1993.

[67] Y. He, Y. J. Cui, W. M. Ye, and N. Conil, "Effects of wettingdrying cycles on the air permeability of compacted Téguline clay,” Engineering Geology, vol. 228, pp. 173-179, 2017.

[68] H. Komine and N. Ogata, "Prediction for swelling characteristics of compacted bentonite," Canadian Geotechnical Journal, vol. 33, no. 1, pp. 11-22, 1996.

[69] R. Pusch and R. N. Yong, Microstructure of Smectite Clays and Engineering Performance, Taylor \& Francis, New York, NY, USA, 2006.

[70] T. Phayak, Experimental Investigations on Small-Strain Stiffness Properties of Partially Saturated Soils via Resonant Column and Bender Element Testing, [Ph.D. Thesis], University of Texas at Arlington, 2006. 

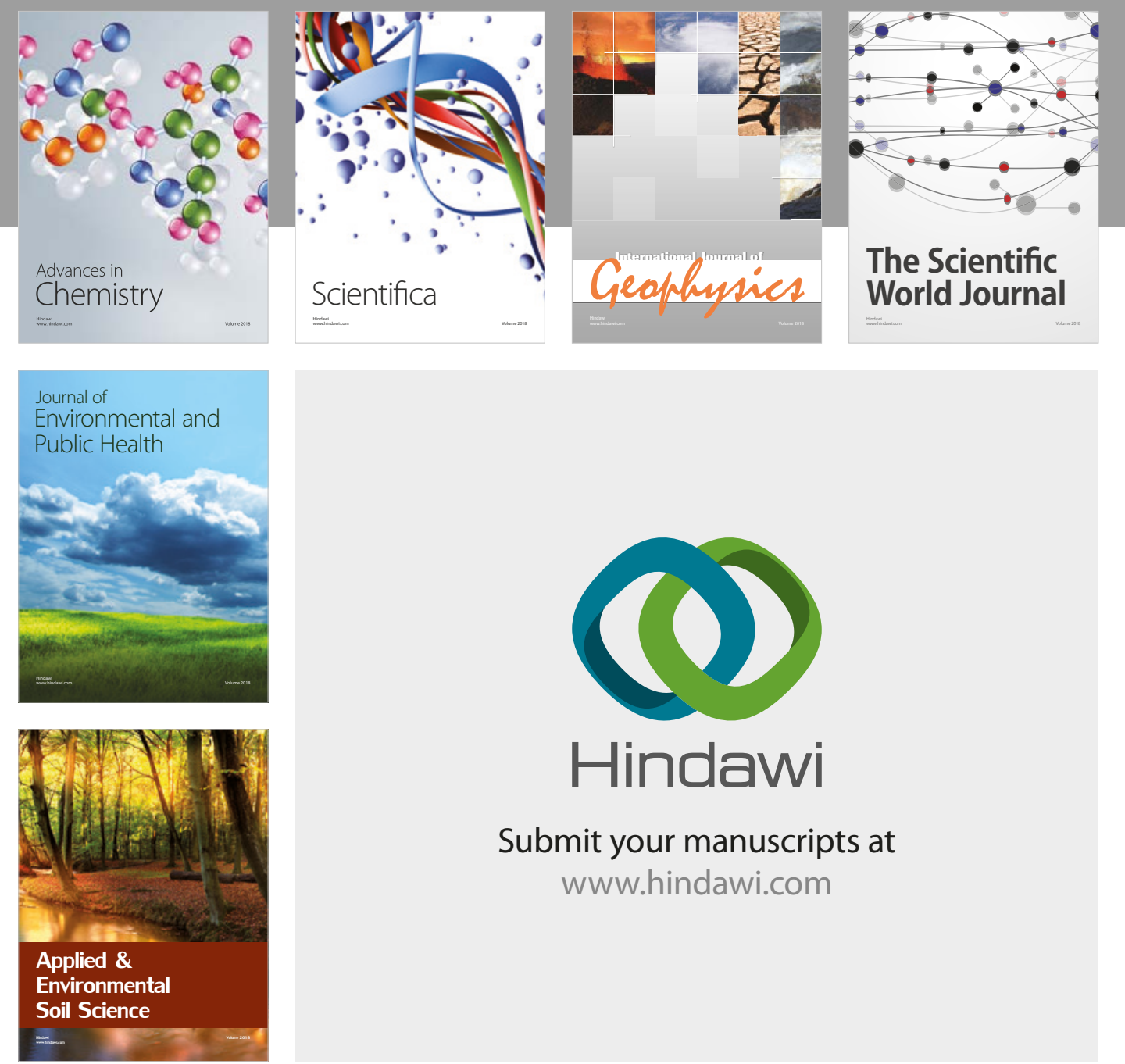

The Scientific

\section{World Journal}
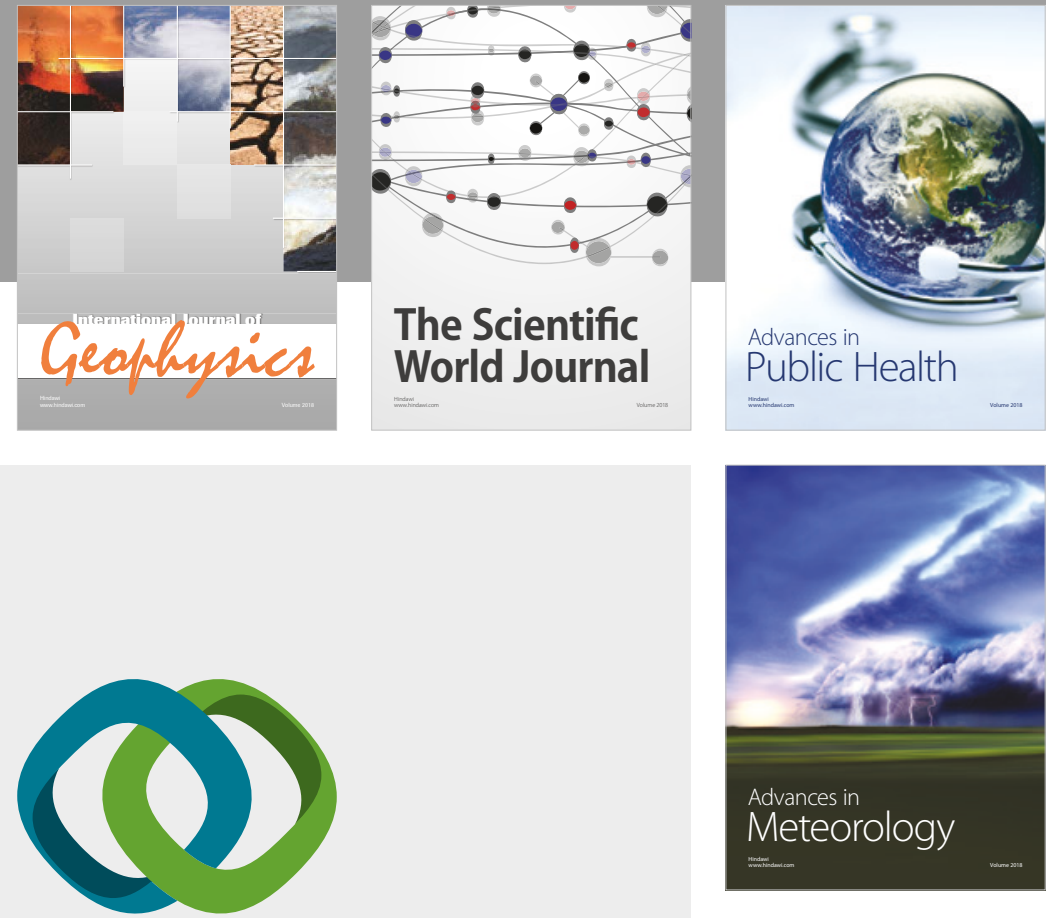

Advan

Public Health

\section{Hindawi}

Submit your manuscripts at

www.hindawi.com
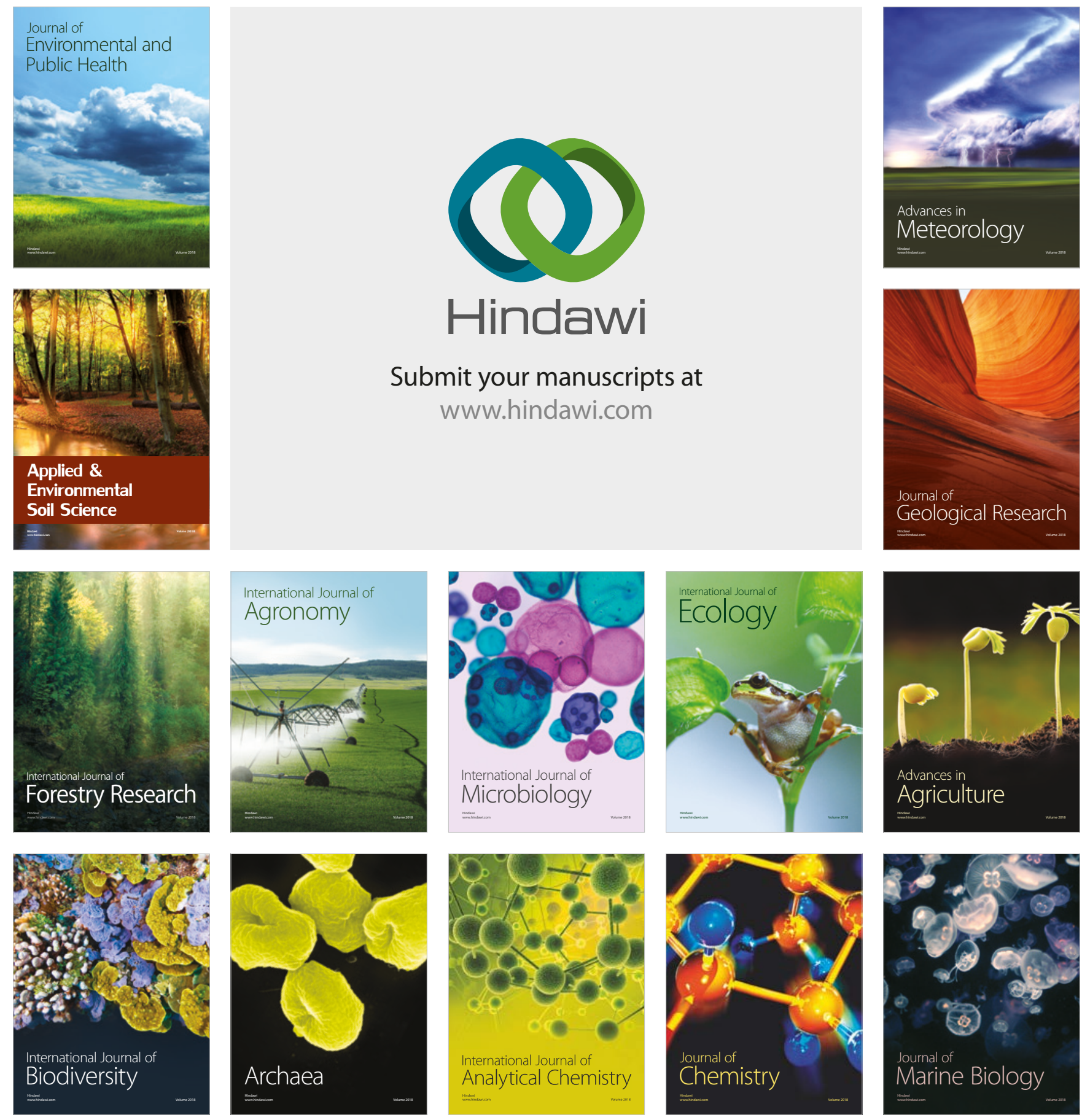